\title{
Metal-Salt Enhanced Grafting of Vinylpyridine and Vinylimidazole Monomer Combinations in Radiation Grafted Membranes for High- Temperature PEM Fuel Cells
}

\author{
Naeimeh Rajabalizadeh Mojarrad, ${ }^{\dagger}$ Sahl Sadeghi, ${ }^{\dagger}$ Begüm Yarar Kaplan, ${ }^{\dagger}$ Enver Güler, ${ }^{*},{ }_{\odot}$ \\ and Selmiye Alkan Gürsel ${ }^{\dagger,+0}$ \\ ${ }^{\dagger}$ Faculty of Engineering and Natural Sciences, Sabanc1 University, İstanbul 34956, Turkey \\ ¥Sabanc1 University Nanotechnology Research \& Application Center (SUNUM), Sabanc1 University, İstanbul 34956, Turkey \\ ${ }^{\S}$ Department of Chemical Engineering and Applied Chemistry, Atılım University, Ankara 06836, Turkey
}

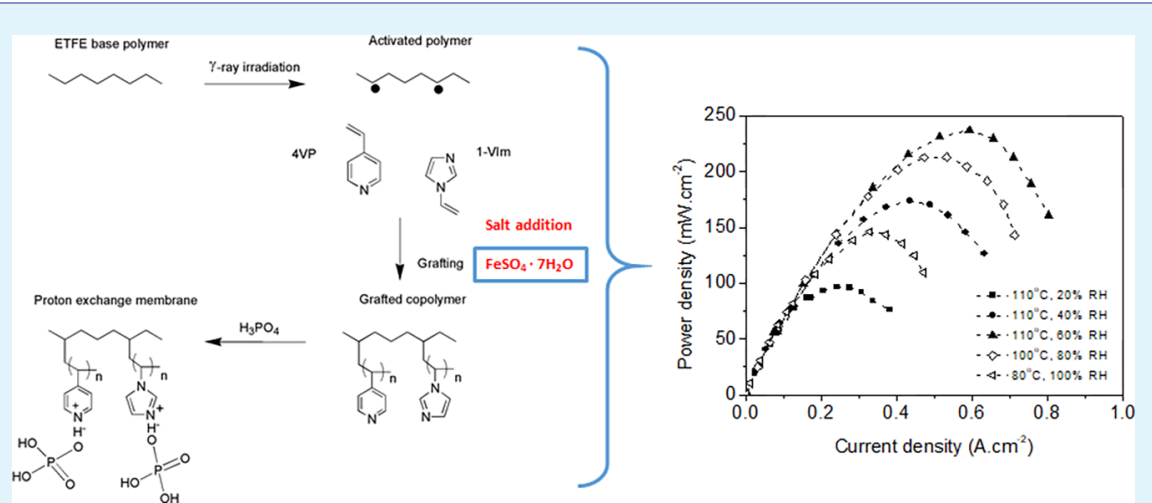

ABSTRACT: Proton exchange membranes were prepared and characterized for utilization in high-temperature proton exchange membrane fuel cells, HT-PEMFCs. 1-vinylimidazole (1-VIm) and 4-vinylpyridine (4VP) monomers were simultaneously grafted onto pre-irradiated ETFE (ethylene-co-tetrafluoroethylene) films which were prepared using $\gamma$-rays with a dose of $100 \mathrm{kGy}$, as a robust substrate to prepare acid-base composite membranes. The grafting reaction was performed at $60{ }^{\circ} \mathrm{C}$ for $24 \mathrm{~h}$ followed by protonation via phosphoric acid doping in the subsequent step. The effect of adding ferrous salts as promoters in grafting was investigated by characterization of resultant membranes via thermal gravimetric analysis and mechanical tests. The fuel cell tests were conducted under different relative humidities (RHs) and applied temperatures. Membranes prepared with salt addition exhibited superior proton conductivities. Results including up to $80 \mathrm{mS} \mathrm{cm}^{-1}$ conductivity at $110^{\circ} \mathrm{C}$ in $60 \% \mathrm{RH}$ and excellent thermal stability, even at $300{ }^{\circ} \mathrm{C}$, suggest these membranes are promising for HT-PEMFC applications.

KEYWORDS: radiation-induced grafting, PEM fuel cell, salt-induced grafting, 1-vinylimidazole, 4-vinylpyridine

\section{INTRODUCTION}

The large contribution of fossil fuels to environmental pollution and global warming in addition to their diminishing supplies versus the growing demand for energy highlights the significance of alternative energy sources. Through a vast amount of research, fuel cells have become one of the most favorable green energy options on the basis of their finite impact on the environment and diverse applicability. ${ }^{1-7}$ Recently, proton exchange membrane fuel cells (PEMFCs) have gained great attention due to their vital characteristics such as quick start-up, high efficiency, a negligible amount of emission, and compact setup, particularly for transportation applications. ${ }^{7,8}$ However, overwhelming efforts are needed to develop the features of the existent PEMFCs, such as their cost and durability, to meet the commercial targets which can be achieved only through the fabrication of new inexpensive materials with desired characteristics, in parallel to optimizing the system design and operating conditions. ${ }^{9-11}$ Increasing the operation temperature of PEMFCs to $100-200{ }^{\circ} \mathrm{C}$ has significant benefits on the overall system performance and cost, not only by depleting the sensitivity of the costly $\mathrm{Pt}$ catalyst particles to $\mathrm{CO}$ contamination but also by providing the possibility of using less purified fuels. In addition, improvement in kinetics of the reactions and simplicity in water/heat management compared to low-temperature PEMFCs can be considered as additional desired aspects of raising the operation temperature. ${ }^{12,13}$

In terms of membrane for high-temperature PEMFCs a proper replacement for the costly Nafion, which is the most relevant membrane material for low-temperature PEMFCs, has

Received: September 11, 2019

Accepted: December 20, 2019

Published: December 20, 2019 
been investigated. Despite the high proton conductivity and reliable chemical stability of Nafion at lower than $100{ }^{\circ} \mathrm{C}$ operation temperature, a drastic decrease in cell performance occurs at elevated temperatures due to their extremely water dependent ionic conductivity and mechanical failure of Nafion. ${ }^{6,14,15}$ Thus, a growing research area is the search for a new generation of membrane materials as the pivotal component of a fuel cell which can provide sufficient lifetime and performance at high operation temperatures and lowhumidity or nonhumidified conditions. Organic-inorganic composite membranes, modified sulfonated hydrocarbon base polymers, and acid-base composite membranes, especially the well-established phosphoric acid doped poly(polybenzimidazole) (PBI/PA) membranes, can be considered as the major developing categories. ${ }^{16-19}$ The last category of the membranes with the amphoteric phosphoric acid offers an alternative proton conductivity mechanism which represents reliable water free ionic conductivity and high thermal/ chemical stability at elevated temperatures (150-200 ${ }^{\circ} \mathrm{C}$ ). However, to overcome the inferior mechanical properties and acid leakage in present acid-doped membranes as the main concerns, various studies have been focused on new strategies. $^{20,21}$ On the other hand, these membranes do not exhibit the same performance at temperatures in the range of $80-120{ }^{\circ} \mathrm{C}$. Consequently, the search for suitable options to meet the requirements for the mentioned temperature range is ongoing. $^{12,22}$

Recently some groups have reported the fabrication of ionic conducting membranes via state-of-the-art radiation-induced grafting (RIG) method. ${ }^{23-25}$ The overall procedure of membrane synthesizing can be done in two or three steps: (a) simultaneous irradiation methodology (the base polymer and monomer are irradiated at the same time; thus, the grafting and irradiation are done in a single step); (b) preirradiation methodology (electron beam or $\gamma$-ray is used to create active radical sites on backbone polymer where the grafting of side chains initiates during the exposure of irradiated samples with chosen monomer solution, and then the resultant copolymers are doped with a proper solution according to their application condition). As the final step, functionalization is necessary to give rise to the introduction of ion conducting characteristic to the grafted copolymer products for both of the procedures.

In previous works, various organic compounds, such as styrene and nitrogen atom containing heterocyclic monomers or vinyl containing monomers, have been used as grafted side chains and perfluorinated or partially fluorinated polymers (i.e., ethylene-co-tetrafluoroethylene (ETFE), poly(vinylidene fluoride) (PVDF), and fluorinated ethylene propylene (FEP)) as backbone polymers for high-temperature proton exchange membrane (HT-PEM) fuel cell applications. Sanli et al. ${ }^{22}$ investigated the properties of PA-doped membranes obtained by RIG method using three different monomers (2VP, 4VP, and NVP) onto pre-irradiated ETFE films, Schmidt and Schmidt-Naake $^{26}$ used 4VP, NVF, and 1-vinylimidazole (1VIm) onto FEP and ETFE films, and Nasef and Hegazy ${ }^{27}$ studied graft copolymerization of 1-VIm onto ETFE in different conditions, for the same purpose. In all cases, proton conductivity of the resultant membranes, as the most important characteristic, was measured at elevated temperatures and low humidity besides the other tests. Furthermore, according to the results of the previous studies, ${ }^{28-30} 1$-VIm could be one of the promising choices for HT-PEM fuel cells due to its high thermal and chemical stability, and also existence of nitrogen atoms in the imidazole ring offers strong basic sites to capture the protons during the acid-doping process. However, there is a need for further exploration of these membranes to evaluate their fuel cell performance at high temperatures and low-humidity values, which are rarely reported.

In addition to the limited studies on fuel cell performances of vinylimidazole based membranes, grafting mechanisms of these vinyl monomers have not been investigated extensively. As such, effects of metal salts on this type of vinylimidazole polymerization have been studied by very few researchers. $^{27,29,31,32}$ It is known today that transition metal salts have been favorably used as promoters in vinyl polymerization. Especially, 1-VIm forms complexes with these metal cations; when added to graft solutions, the redox initiation is promoted providing high grafting yields. ${ }^{29}$

In this work, combinations of 1 -VIm and 4VP monomers were used as hydrophilic side chains to graft on hydrophobic pre-irradiated ETFE films as a backbone polymer. The protonation process was done by using phosphoric acid. The effects of ferrous salt addition on the grafting yield, fuel cell performance, and thermal and mechanical behaviors of synthesized membranes were studied. Ionic conductivity and fuel cell test data of the resultant membranes at different temperatures and relative humidity levels were reported.

\section{EXPERIMENTAL SECTION}

2.1. Materials. ETFE films of $25 \mu \mathrm{m}$ thickness were purchased from Nowofol GmbH (Siegsdorf, Germany). 1-VIm (purity > 99\%), 4VP (purity > 99\%), 2-propanol, tetrahydrofuran, iron(II) sulfate heptahydrate (purity $>99 \%$ ), phosphoric acid (purity > 85\%), and hydrochloric acid (purity > 99\%) were obtained from Sigma-Aldrich and used as received.

2.2. Irradiation of ETFE Films. ETFE films were cut into $8 \mathrm{~cm} \times$ $8 \mathrm{~cm}$ sheets. The prepared films were rinsed with ethanol very carefully and dried in a vacuum oven overnight at $60^{\circ} \mathrm{C}$. The films were kept in thin polyethylene bags. Irradiation of the films was done by $\gamma$-rays from a ${ }^{60} \mathrm{Co}$ source with the total irradiation dose of 100 $\mathrm{kGy}$ at room temperature. To protect the active free radicals which were created during irradiation, the irradiated films were carried in dry ice to our laboratory and stored in a low-temperature freezer at -60 ${ }^{\circ} \mathrm{C}$ until further use. ${ }^{33-36}$

2.3. Graft Copolymerization. The glass reactors were filled with reaction mixtures with the compositions as reported in Table 1 for three distinct experimental sets. The prepared mixtures were purged with nitrogen gas for $15 \mathrm{~min}$ to provide an inert atmosphere. Then, the pre-irradiated films were immersed in the mixture immediately and the reactors were sealed tightly. Nitrogen purging continued for another $15 \mathrm{~min}$ after immersing the films in the solution. The graft

Table 1. Composition of the Grafting Mixtures

\begin{tabular}{ccccc} 
set & $\begin{array}{c}\text { solvent type } \\
(\text { amount })\end{array}$ & $\begin{array}{c}\text { VIm ratio } \\
\left(V_{1-V I m}: V_{4 \mathrm{VP}}\right)\end{array}$ & $\begin{array}{c}\text { total monomer } \\
\text { concn }(\% ; \mathrm{v} / \mathrm{v})\end{array}$ & $\begin{array}{c}\mathrm{FeSO}_{4} \cdot 7 \mathrm{H}_{2} \mathrm{O} \\
(\mathrm{mg})\end{array}$ \\
\hline & $\begin{array}{c}\text { IPA-THF } \\
(2 \mathrm{~mL} / 4 \mathrm{~mL})\end{array}$ & $0: 1$ to $1: 0$ & 50.0 & 0 \\
2 & $\mathrm{H}_{2} \mathrm{O}(4.8 \mathrm{~mL})$ & $1: 1$ & & 0 \\
& ethanol $(4.8 \mathrm{~mL})$ & $1: 1$ & 60.0 & 0 \\
& $\mathrm{H}_{2} \mathrm{O}-$ ethanol & $1: 1$ & 60.0 & 0 \\
& $(2.4 \mathrm{~mL} / 2.4 \mathrm{~mL})$ & & 60.0 & 150 \\
3 & $\mathrm{H}_{2} \mathrm{O}(1.5 \mathrm{~mL})$ & $1: 0$ & & 150 \\
& & $1: 1$ & 87.5 & 0
\end{tabular}


copolymerization reactions were conducted on an agitated thermostat at $60{ }^{\circ} \mathrm{C}$ for $24 \mathrm{~h}$.

After grafting in glass reactors, samples of set 1 and set 2 were washed in ethanol overnight to remove unreacted monomer, which was followed by a drying step for $24 \mathrm{~h}$ in the oven at $60^{\circ} \mathrm{C}$. For the third set of experiments the same synthesizing condition was applied; however, the washing step was done in $1 \mathrm{M} \mathrm{HCl}$ overnight and followed by subsequent washing in deionized water. The temperature and duration of the drying process were the same as for previous sets.

In the first set of the experiments, the volumetric ratio of 1-VIm to 4VP (VIm ratio) was altered to achieve the optimum ratio with reasonable graft level for the subsequent set of experiments (Table 1). In those experiments, the monomer to solvent (IPA-THF mixture) volumetric ratio was kept constant. The second set was conducted with constant solvent to monomer volumetric ratio (40:60), as well as a fixed VIm ratio (50:50), but with altering the solvent type. Finally, to compare the effect of adding iron(II) sulfate heptahydrate $\left(\mathrm{FeSO}_{4}\right.$. $7 \mathrm{H}_{2} \mathrm{O}$ ) on the obtained graft level, two different kinds of membranes were produced: one with the addition of salt as an additive and the other in the absence of salt, where the volume ratio of the monomer to solvent (water) was 87.5:12.5.

The graft level (GL, \%) of the irradiated ETFE films was determined by the equation as follows:

$$
\mathrm{GL} / \%=\frac{m_{\mathrm{G}}-m_{0}}{m_{0}} \times 100
$$

where $m_{0}$ and $m_{\mathrm{G}}$ are the weight of film before and after grafting, respectively.

2.4. Membrane Preparation. The protonation of grafted films to obtain membrane functionality was carried out via immersing them in phosphoric acid $(85 \%)$ for $20 \mathrm{~h}$ at $60{ }^{\circ} \mathrm{C} .{ }^{22,28,36}$ Acid-doped films in sets 1 and 2 were washed with distilled water for $24 \mathrm{~h}$ to rinse the excess acid. Then the samples were dried overnight in an oven at 60 ${ }^{\circ} \mathrm{C}$. The acid uptake of the membranes was determined by the following equation:

$$
\mathrm{AD} / \%=\frac{m_{\mathrm{A}}-m_{\mathrm{G}}}{m_{\mathrm{G}}} \times 100
$$

where $m_{\mathrm{G}}$ and $m_{\mathrm{A}}$ are the weight of film after grafting and after acid doping, respectively. Membrane preparation steps including preirradiation followed by grafting and acid doping were shown in Figure 1 .

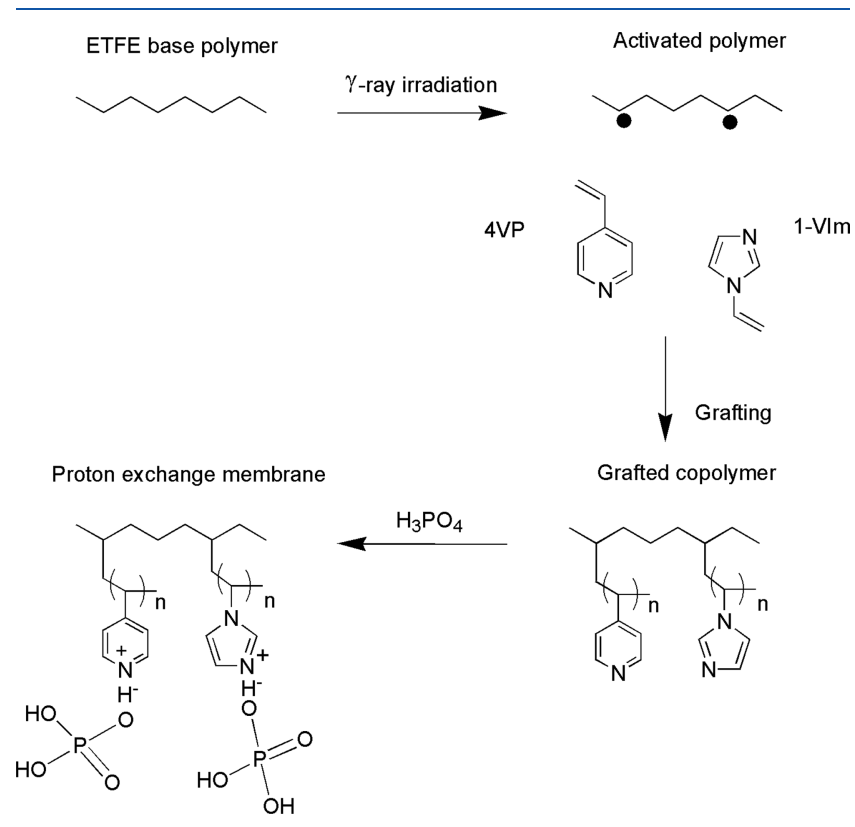

Figure 1. Schematic of the membrane preparation steps.
2.5. Characterization. For measuring the ionic conductivity of the membranes at room temperature and in fully humidified condition, samples of $2 \mathrm{~cm} \times 2.5 \mathrm{~cm}$ in size were cut from the membranes. Then, to bring each sample to equal humidified condition and make a benchmarking at fully humidified conditions, they were immersed in deionized water for $4 \mathrm{~h}$ before measurement. Each sample was placed in the BekkTech conductivity cell equipped with a Gamry Reference 3000 potentiostat/galvanostat system (Gamry Instruments, USA) that was used to conduct four-probe conductivity measurements by electrochemical impedance spectroscopy. The ionic conductivity was obtained as follows:

$$
\sigma /(\mathrm{S} / \mathrm{cm})=\frac{L}{R \times W \times T}
$$

$R$ stands for resistance $(\Omega), T$ is the thickness of the membrane after acid doping $(\mathrm{cm})$, and $W$ and $L$ are constant dimensions that represent the width of the sample $(2 \mathrm{~cm})$ and the distance between the probes $(0.425 \mathrm{~cm})$, respectively.

In order to investigate the conductivity behavior of prepared membranes at fuel cell conditions, ionic conductivity of membranes at varying humidity and elevated temperature conditions were investigated as well. These measurements were conducted under controlled temperature in the range of $80-110{ }^{\circ} \mathrm{C}$ and relative humidity (RH) in the range of $20-100 \%$, by BekkTech four-pointprobe conductivity setup and Scribner $850 \mathrm{e}$ fuel cell test station. The membranes were tested after acid doping without immersing them in water.

FTIR spectroscopy was carried out for ETFE base film, 1-VIm, 4VP as reference materials, and prepared membranes using Bruker Equinox 55 equipment in the range of 500 to $4000 \mathrm{~cm}^{-1}$.

To verify the success of grafting of 1 -VIm and 4VP onto ETFE, magic-angle spinning (MAS) solid-state NMR $\left({ }^{13} \mathrm{C}-\mathrm{MAS}\right.$ NMR) was performed for pristine ETFE film and ETFE-g-(1-VIm-4VP) copolymers by Varian Unity Inova AS500 spectrometer, $11.74 \mathrm{~T}$, at $500 \mathrm{MHz}$.

For the stress-strain mechanical tests of the resultant membranes, a universal tensile machine (Zwick/Roell Z100) at 60\% RH at room temperature was used as described previously. ${ }^{36,37}$ The ASTM D882 standard test method was used to determine tensile properties in which the elongation rate was set to $100 \mathrm{~mm} / \mathrm{min}$. A minimum of three specimens for each sample was used.

Thermogravimetric analysis (TGA) was conducted at the rate of 10 ${ }^{\circ} \mathrm{C} /$ min up to $800{ }^{\circ} \mathrm{C}$ by means of Shimadzu DTG-60 under $\mathrm{N}_{2}$ atmosphere.

The fuel cell performances of the most promising membranes (set 3 membranes) were performed by Scribner 850e fuel cell system. Prior to this test, selected samples were used to fabricate membrane electrode assemblies (MEAs) without previously immersing them into water. For that purpose, the membrane was placed between $5 \mathrm{~cm}^{2}$ two commercial (0.4 mg Pt/ $\mathrm{cm}^{2}$ loading) electrodes ${ }^{38}$ (Fuel Cell Store, USA) and hot-pressed by applying $2 \mathrm{MPa}$ pressure for $5 \mathrm{~min}$ after a preheating step of $10 \mathrm{~min}$ at $135^{\circ} \mathrm{C}$ without applying pressure. The fuel cell tests were performed in various humidity conditions at 80 , 100 , and $110{ }^{\circ} \mathrm{C}$ with $500 \mathrm{~cm}^{3} / \mathrm{min}$ of $\mathrm{H}_{2}$ and $\mathrm{O}_{2}$.

\section{RESULTS AND DISCUSSION}

3.1. Effect of Monomer Combinations on Graft Level and Acid Uptake. In the first set of experiments, the effects of monomers' volumetric ratio on the graft level, acid-doping level, and ionic conductivity of the fabricated membranes were investigated at room temperature when the total monomer concentration with respect to solvent is constant. Considering the poor reactivity of $1-\mathrm{VIm}$ compared to $4 \mathrm{VP}$ in grafting as we have also experienced in our previous work, ${ }^{36}$ the graft level increased with increasing of the concentration of 4VP in the reaction mixture, as shown in Figure 2. 


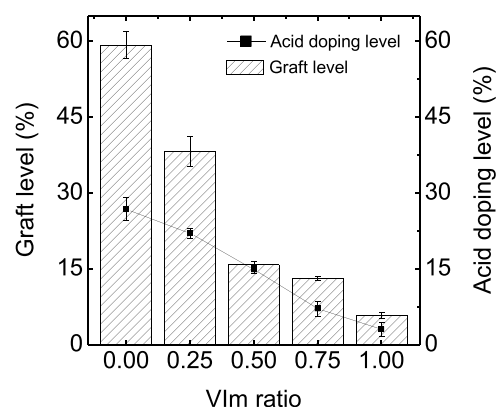

Figure 2. Effect of 1-VIm concentration on graft level.

A $6 \%$ graft level is achieved when only $1-$ VIm is used in the grafting mixture, whereas it is almost a $60 \%$ graft level with the use of 4VP only.

The composition of grafting solutions and characteristics of synthesized membranes are given in Table 1 . As it will be realized in the following sections, the graft level is considered as the source parameter that determines the following characteristics of the resultant membranes. ${ }^{39}$

Phosphoric acid groups interact with the nitrogen atoms present in the chemical structure of the grafted vinyl rings which act as the basic centers. Therefore, the acid-doping level of the resultant copolymers has a direct relationship with the graft level, because an increased number of grafted sites leads to a higher amount of basic centers being provided for the acid groups to attach, which is also reflected in Figure 2.

The level of acid uptake with respect to the 1-VIm ratio, which is based on the experimental data used in eq 2, reveals the significant contribution of the grafted side chains that are protonated by acid. In addition, grafts of less hydrophobic polymers on the base polymer promotes further swelling of the hydrophobic ETFE polymer film that ends up with the higher number of protonated branches. According to the obtained data for the sample with 0.5 VIm ratio, although the graft level is four times less than that of the zero VIm ratio (Figure 2), the acid-doping level of the membrane prepared with the solution having 0.5 VIm ratio is just half of the one with the zero VIm ratio. This evidence can be referred to as the higher basicity of $1-\mathrm{VIm}$ with $\mathrm{p} K_{\mathrm{b}}=6.6$ than that of $4 \mathrm{VP}$ with $\mathrm{p} K_{\mathrm{b}}=8.0$ due to one more $\mathrm{N}$ atom in its structure. ${ }^{26}$ Another finding that is worthwhile to mention is that up to a certain level of 1-VIm addition to monomer combinations promotes higher ratios of acid-doping levels with respect to graft levels. For instance, the sample with 0.501 -VIm ratio has the highest level of acid doping with respect to its specific graft level (Figure 2). This observation may stem from the possibility of homopolymerization at higher graft levels of 4VP.

3.2. Effect of Solvent Type on Graft Levels of Monomers. The graft level of copolymers is strongly dependent on the type of solvents used in grafting solutions. The yield of grafting is based on the diffusion of monomers into the base films. In that sense, when the solvent system leads the base film swelling, it enhances the diffusion of the monomers. This mechanism is also named as the grafting front mechanism in the literature. ${ }^{40}$ This diffusion is estimated by the close proximity of the solubility parameters of grafting components, i.e., monomers and the solvents. According to a previous study based on styrene/ETFE grafting, addition of water to 2-propanol enhanced the graft level significantly. ${ }^{41}$ This shows that alcohols in combination with water could yield high graft levels. However, Işıkel Şanlı and Alkan Gürsel observed no improvement in grafting 4VP onto ETFE based on the fact that addition of water increases the difference in solubility parameters of the monomer and the solvents. ${ }^{35}$

In this work, first, water was used as solvent for the grafting of the 1-VIm/4-VP mixture. However, a graft level of $17 \%$, the same as water/ethanol mixture, was observed. The solubility parameter of water is as high as that of 1 -VIm, which is not relatively active in grafting (Table 2 ). Thus, using water solely

Table 2. Solubility Parameter of Solvents and Solvent Pairs (Reprinted with Permission from Reference 42. Copyright 2008 John Wiley and Sons)

\begin{tabular}{|c|c|}
\hline solvent & $\delta\left(\mathrm{cal} \mathrm{cm}^{-3}\right)^{1 / 2 a}$ \\
\hline 1-VIm & 27.5 \\
\hline $4-\mathrm{VP}$ & 11.0 \\
\hline $1-\mathrm{VIm} / 4-\mathrm{VP}(1: 1, \mathrm{v} / \mathrm{v})^{b}$ & 19.2 \\
\hline water & 23.4 \\
\hline ethanol & 12.9 \\
\hline water-ethanol $(1: 1, \mathrm{v} / \mathrm{v})^{b}$ & 18.2 \\
\hline
\end{tabular}

${ }^{a} \delta=$ solubility parameter. ${ }^{b}$ Solubility parameters of mixtures are estimated according to the following equation:

$$
\delta_{\text {mix }}=\frac{\delta_{1} X_{1} V_{1}+\delta_{2} X_{2} V_{2}}{X_{1} V_{1}+X_{2} V_{2}}
$$

where $\delta_{\text {mix }}$ is the mixture solubility parameter, $X_{1}$ and $X_{2}$ are molar fractions, and $V_{1}$ and $V_{2}$ are molar volumes of components 1 and $2{ }^{43}$

as solvent has no advantage in grafting over other solvent or solvent mixtures (Table 3 ). On the other hand, using ethanol

Table 3. Key Properties of Prepared Membranes ${ }^{a}$

\begin{tabular}{|c|c|c|c|c|c|}
\hline expt & variable param & $\begin{array}{l}\text { thickness } \\
(\mu \mathrm{m})\end{array}$ & $\begin{array}{c}\text { graft } \\
\text { level } \\
(\%)\end{array}$ & $\begin{array}{c}\text { acid } \\
\text { doping }\end{array}$ & $\begin{array}{l}\text { conductivity } \\
(\mathrm{mS} / \mathrm{cm})\end{array}$ \\
\hline \multirow[t]{6}{*}{ set 1} & VIm ratio $^{b}$ & & & & \\
\hline & 0.00 & 41 & 59 & 27 & 19 \\
\hline & 0.25 & 39 & 38 & 22 & 16 \\
\hline & 0.50 & 33 & 16 & 15 & 12 \\
\hline & 0.75 & 30 & 13 & 7 & 6 \\
\hline & 1.00 & 26 & 6 & 3 & 3 \\
\hline \multirow[t]{4}{*}{ set 2} & solvent type ${ }^{c}$ & & & & \\
\hline & $\mathrm{H}_{2} \mathrm{O}$ & 33 & 17 & 19 & 14 \\
\hline & ethanol & 36 & 25 & 26 & 11 \\
\hline & $\mathrm{H}_{2} \mathrm{O} /$ ethanol & 32 & 17 & 13 & 10 \\
\hline \multirow[t]{3}{*}{ set 3} & salt addition $^{d}$ & & & & \\
\hline & without salt & 41 & 34 & 121 & 38 \\
\hline & salt added & 40 & 36 & 145 & 50 \\
\hline
\end{tabular}

${ }^{a}$ Errors from the measurements are small and, thus, omitted for visual clarity. ${ }^{b}$ Solvent used was IPA-THF mixture. ${ }^{c}$ A 1-VIm:4VP grafting solution with 1:1 volume ratio was used. ${ }^{d}$ Water was used as solvent in 1-VIm:4VP grafting solution with 1:1 volume ratio.

only in grafting solution yields the highest graft level due to its close proximity to a relatively more active 4VP. A $25 \%$ graft level was achieved with ethanol. Nevertheless, when water was mixed to ethanol, the graft level did drop again due to its solubility parameter, which is close to the one of 1 -VIm. Close proximity of mixture solubility parameters did not help in high graft levels. It is assumed that the determining factor in graft levels is the grafting activity of the monomers. Chain transfer 
effect or wetting of the graft solution with ETFE may have also affected the level of monomer grafting.

3.3. Effect of Salt Addition on Graft Level and Acid Uptake. Addition of metal salts, such as iron or zinc salts, promote the grafting of vinyl monomers such as imidazoles onto pre-irradiated ETFE films. ${ }^{29,31}$ Especially in preirradiation grafting systems, peroxide formation is very likely resulting in decreased monomer grafting. ${ }^{29}$ Iron salts may help decomposition of peroxide species, thus resulting in a significant increase in growing chain radicals. In addition, redox initiation effects and complex formation of metal salts are other factors affecting the polymerization. ${ }^{31}$ Schmidt and Schmidt-Naake obtained maximum degrees of 1-VIm grafting for a concentration between 10 and $50 \mathrm{mmol} \mathrm{L}^{-1}$ of $\mathrm{FeSO}_{4}$. $7 \mathrm{H}_{2} \mathrm{O}$ salt. $^{29}$

In Table 3, it is shown that salt addition promoted acid uptake of the membranes, although this promotion is lower in graft levels of monomers. In the presence of the metal salt, complex formation is more likely to occur. Thus, steric effects in the pyridine and imidazole groups may be reduced by these complexes, allowing high levels of acid uptake. Certainly, more elaborate study is required to fully understand this behavior. Salt effects on vinyl polymerization are well explained by Tazuke and Okamura.

3.4. Water Uptake. Water uptake of acid-doped membranes is generally associated with the acid content of the membranes. ${ }^{44}$ It is expected to get higher water uptakes with high levels of acid uptake. However, when active sites of the imidazole ring are occupied by the acid molecules, this may suppress the water uptake tendency of the membrane to some extent. In Figure 3, water uptake levels of prepared membranes

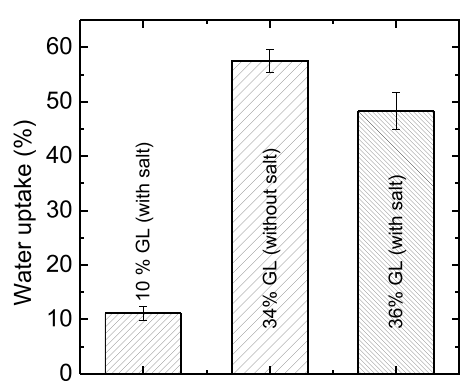

Figure 3. Water uptake of the phosphoric acid-doped samples of 10, 34 , and $36 \%$ GL from set 3 .

are shown. In the case of salt-added grafting, water uptake increases with increasing graft level. For the membranes with similar graft levels (34\% and 36\% GL membranes were chosen with sufficient level of ionic conductivity which contain both 1VIm and 4VP monomers), salt-added membrane exhibited slightly lower water uptake, although its acid doping level is considerably high at $145 \%$ (Table 3 ). This behavior may arise from the fact that active sites of the imidazole and pyridine rings, which also contribute to water uptake, are occupied. Obtained water uptakes with salt-added membranes represent moderate levels that are sufficient to provide desired mechanical properties.

3.5. Proton Conductivity. Proton conductivity of the third set was measured at elevated temperatures $(80,100$, and $110{ }^{\circ} \mathrm{C}$ ) and varying relative humidity (from 20 to $100 \%$ ). The graphs of ionic conductivity versus $\mathrm{RH}$ percentage at each applied temperature represent a growing trend in terms of conductivity with increasing temperature for both of the samples (Figure 4). Moreover, the obtained data indicate that humidity has a positive effect on the enhancement of the (a)

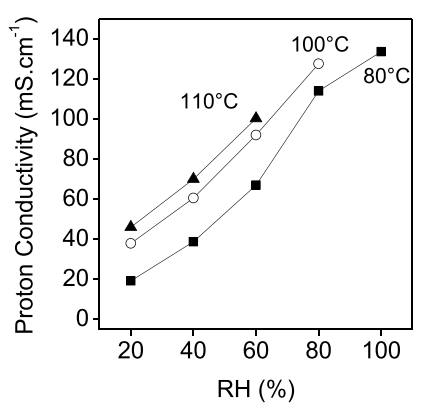

(b)

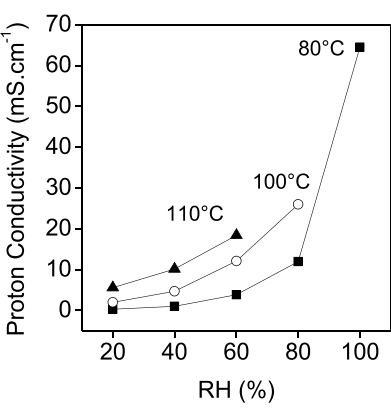

Figure 4. Proton conductivity of set 3 membranes: (a) 36\% GL with salt addition and (b) 34\% GL without salt addition.

membrane conductivity. Applying high temperatures provides more activation energy for charge carriers that results in enhancement of their mobility, in addition, the existence of humidity facilitates the proton transfer due to the improvement of their diffusion (Grotthuss mechanism) through the membrane. ${ }^{45}$ However, the membrane with salt (36\% GL) shows superior conductivities in all test conditions, which is evidence for a higher graft level and acid-doping level. At the highest test temperature $\left(11{ }^{\circ} \mathrm{C}\right)$, salt-added membrane exhibited five times higher conductivity when compared to the one without salt addition. At the lowest $\mathrm{RH}$, this membrane still provided almost 9-fold higher conductivity values compared to its counterpart.

3.6. FTIR Analysis. FTIR spectroscopy was done to prove successful grafting of the 1-VIm and 4VP monomers onto the ETFE backbone. As shown in Figure 5, FTIR spectra of

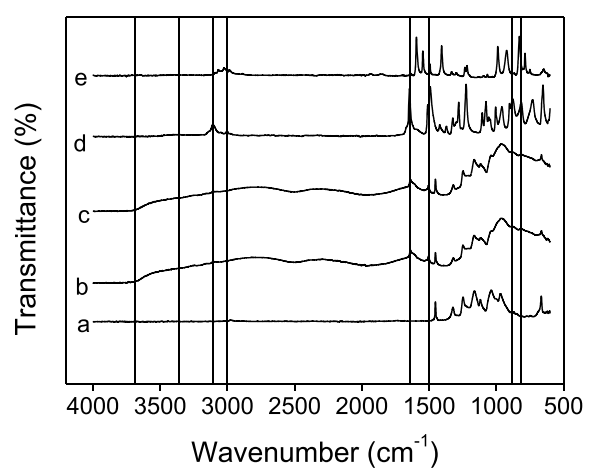

Figure 5. FTIR spectra of (a) ETFE, (b) ETFE-g-4VP-VIm 34\% GL, (c) ETFE-g-4VP-VIm 36\% GL, (d) 1-VIm, and (e) 4-VP.

pristine ETFE film, liquid 1-VIm and 4VP monomers were used as reference to compare with spectra of the grafted samples of 34\% GL and 36\% GL. Appearance of additional peaks for grafted samples was observed in the ranges of 745$890,1490-1550$, and $1610-1670 \mathrm{~cm}^{-1}$ that correspond to the $\mathrm{C}-\mathrm{H}$ ring mode and $\mathrm{C}-\mathrm{N}$ and $\mathrm{N}-\mathrm{H}$ stretching, respectively. The emergence of the less intense peaks in the wavenumber ranges of the $2990-3120$ and $3200-3500 \mathrm{~cm}^{-1}$ are attributed to the combinations of $\mathrm{N}-\mathrm{H}$ and $\mathrm{C}-\mathrm{H}$ bonds to create a $\mathrm{H}$ bonding network. ${ }^{28,29,46}$

3.7. Solid-State ${ }^{13}$ C-MAS NMR Spectroscopy. The solid-state ${ }^{13} \mathrm{C}$-MAS NMR spectral analysis of ETFE and 
ETFE-g-(1-VIm-4VP) copolymer was carried out for confirmation of covalently bonded imidazole rings onto the ETFE film. As shown in Figure 6, the signals corresponding to $42-85$

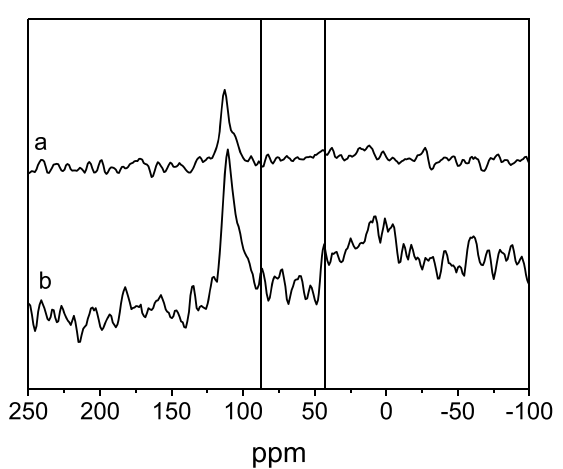

Figure 6. NMR spectra of (a) ETFE and (b) ETFE-g-(1-VIm, 4VP).

ppm are the evidence for formation of covalent bond between carbon atoms of backbone polymer and nitrogen atoms of imidazole ring, and the signal at $136 \mathrm{ppm}$ stands for the imidazole ring. ${ }^{47,48}$

3.8. Thermal Analysis. Thermal behavior of the membranes was studied via thermal analysis under $\mathrm{N}_{2}$ atmosphere with the $10{ }^{\circ} \mathrm{C} \cdot \mathrm{min}^{-1}$ heating rate (Figure 7). A

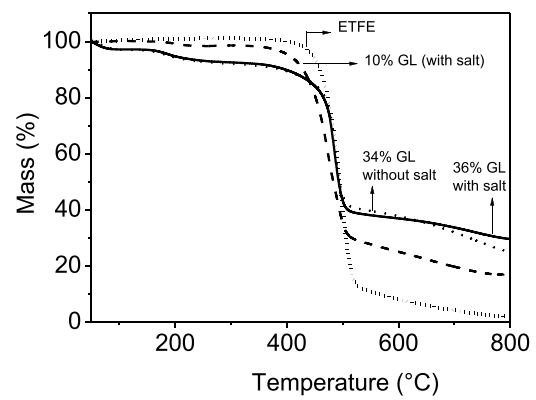

Figure 7. Thermal analysis of the phosphoric acid-doped samples of 10,34 , and $36 \%$ GL from set 3 and pristine ETFE film.

single step degradation thermogram with a sharp weight loss, starting at $450{ }^{\circ} \mathrm{C}$, corresponds to pristine ETFE film as reported in previous works. ${ }^{28,29}$ However, four-stepped curves relate to the acid-doped samples, which is in good agreement with the existence of grafted polyvinyl rings and phosphoric acid groups onto the base polymer. The first two gradual mass losses at temperatures around 100 and $200{ }^{\circ} \mathrm{C}$ indicates the evaporation of absorbed moisture from air via hydrophilic phosphoric acid groups and dehydration of acid groups, respectively. In the following, step decomposition of P (1-VImco-4VP) occurred between 260 and $300{ }^{\circ} \mathrm{C}$ for the grafted membranes. In contrast to previous stages, a remarkable weight loss from 420 to $480{ }^{\circ} \mathrm{C}$ can be seen in the final step, revealing the degradation of the base matrix for all samples.

3.9. Mechanical Properties. The tensile tests of promising acid-doped membranes were performed, that is to say, membranes with $10 \%$ graft level (with salt), $34 \%$ graft level (without salt), and 36\% graft level (with salt) as shown in Figure 8 . The samples were cut with 1:10 aspect ratio, and the elongation rate was set to $100 \mathrm{~mm} / \mathrm{min}$. The graphs revealed that the doping of copolymer films with phosphoric acid has inversely affected the mechanical behavior of the membranes.

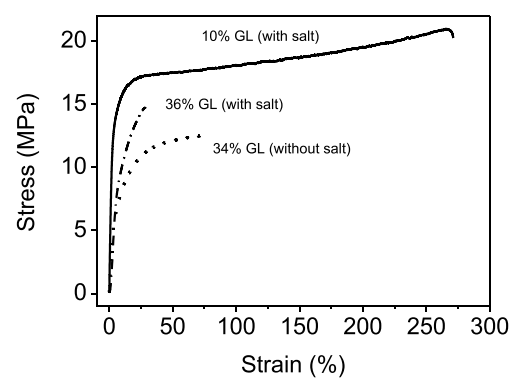

Figure 8. Schematic of the stress-strain curves of membranes.

By increasing the graft level further, acid groups were introduced to copolymer structure, which affected the mechanical stability as expected. Moreover, adding the ferrous salt caused enhancement of the strength of the membranes; however, 36\% GL membrane shows less elongation compared to $34 \% \mathrm{GL}$ membrane. This behavior may also be correlated to the water uptake levels of the highly grafted membranes (Figure 3). Salt addition to graft solution slightly causes lower water uptake resulting in lower elongation in tensile tests.

3.10. Single-Cell Tests. Despite the several numbers of reports about membrane preparation via radiation-induced grafting membranes, there is a limited number of studies in the literature which reported fuel cell performance of the resultant membranes. It is worthwhile to investigate the performance of these cost-effective membranes in the harsh operation condition of the cell. ${ }^{22,26,37}$ Therefore, fuel cell tests were carried out for selected membranes as a function of relative humidity and temperature, using $500 \mathrm{~cm}^{3} / \mathrm{min}$ of $\mathrm{H}_{2}$ and $\mathrm{O}_{2}$. Polarization and power output curves of $36 \%$ GL and $34 \%$ GL membranes are shown in Figure 9. The polarization curves were obtained at 80,100 , and $110^{\circ} \mathrm{C}$ cell temperature under $20,60,80$, and $100 \%$ relative humidity. As expected from the previous characterization results, the membrane with $36 \% \mathrm{GL}$ exhibited comparatively superior fuel cell performance. As depicted in Figure 9 and Figure 10, maximum achieved power density of $237 \mathrm{~mW} \cdot \mathrm{cm}^{-2}$ is provided by salt-added membrane with $36 \% \mathrm{GL}$ at $110{ }^{\circ} \mathrm{C}$ and $60 \% \mathrm{RH}$ that can be considered as comparable performance with 150,75 , and $220 \mathrm{~mW} \cdot \mathrm{cm}^{-2}$ at $120{ }^{\circ} \mathrm{C}$ for ETFE/P1-VIm/PA, ETFE/PVAm/PA, and PA/ PBI membranes, respectively, which have been reported previously. ${ }^{30,35}$ Despite some differences compared to the literature, obtained polarization curves show a similar increasing trend for the maximum power density with the enhancement of the temperature and relative humidity for both membranes (Figure 9). The aforementioned behavior confirms the previous conductivity results for the same samples, which indicates the drastic reliability of the proton conduction to the mobility of charge carriers as the function of temperature as well as to the ease of their diffusion in humidified condition. ${ }^{12,22,26}$

The effect of salt addition during membrane fabrication on power density is clearly visible when polarization curves in Figure $9 \mathrm{~b}, \mathrm{~d}$ are compared as salt addition promoted acid uptake and subsequently the conductivity as discussed earlier. This effect is enhanced with the temperature increase as well. Consequently, it can be deduced that the resultant membranes may represent promising alternatives for HT-PEM fuel cells, as they could sustain the proton conducting behavior at high temperature and in moderate $\mathrm{RH}$ conditions. 
(a)

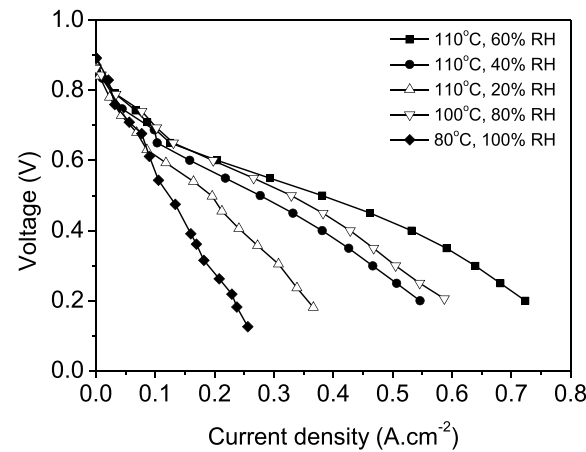

(c)

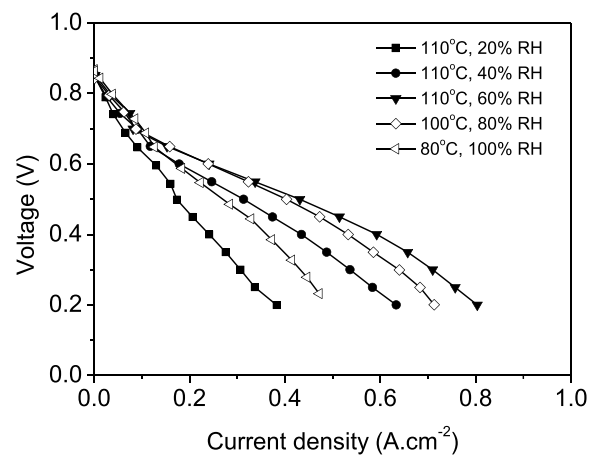

(b)

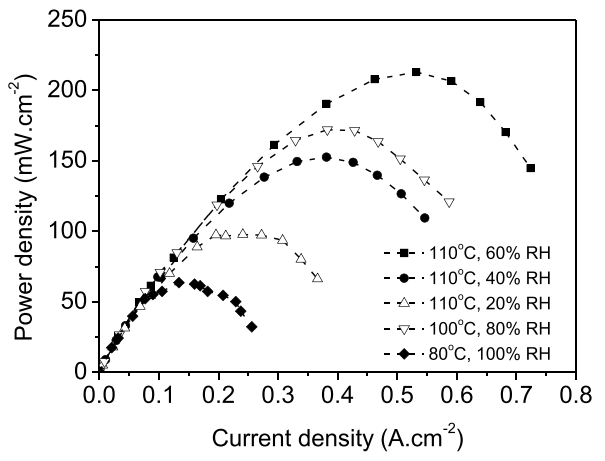

(d)

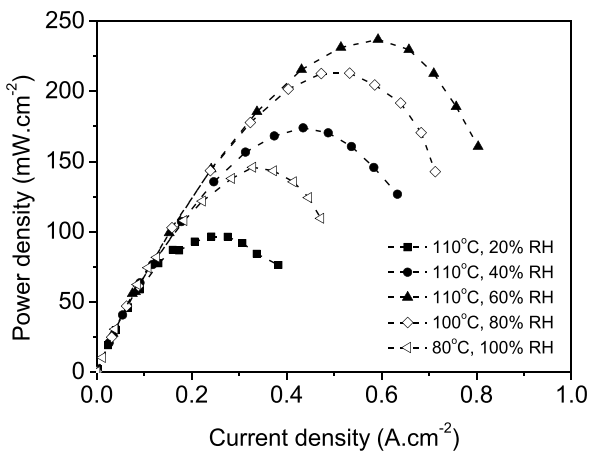

Figure 9. $\mathrm{H}_{2} / \mathrm{O}_{2}$ PEM fuel cell: (a) polarization curves and (b) power density curves for the $36 \%$ GL (without salt); (c) polarization curves and (d) power density curves for the $34 \%$ GL (with salt) at different temperatures and relative humidity (\%).

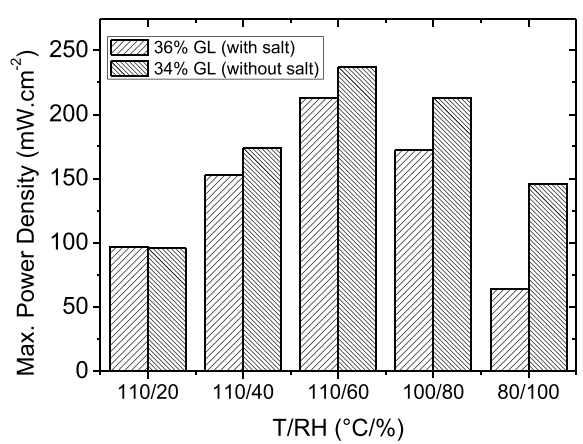

Figure 10. Maximum power densities at varying temperature and relative humidity.

\section{CONCLUSION}

In the present study, novel polymeric proton-conducting membranes were fabricated by radiation-induced grafting using monomer combinations of 4VP and 1-VIm for the first time. ETFE-g-P1-VIm/4VP copolymer films were synthesized successfully using a facile and versatile radiation-induced grafting technique and then fabricated as proton exchange membranes after doping with phosphoric acid. To identify the optimum composition of grafting solutions, several samples with different component ratios were fabricated and investigated through various characterization techniques. Furthermore, a fuel cell test was carried out for each selected membrane sample at different temperatures and relative humidities to quantify their proton conductivities at temperatures more than the boiling point of water and lower levels of humidity. Salt addition provided an enhancement both in monomer grafting and acid-doping levels in prepared membranes. Mechanical tests, TGA analysis, ex situ conductivity measurements at 80,100 , and $110^{\circ} \mathrm{C}$ at various $\mathrm{RHs}$, and fuel cell tests reveal their superior properties at elevated temperatures and low-humidity levels. As a consequence, they can be considered as potential membranes for intermediate or high-temperature fuel cell systems.

\section{AUTHOR INFORMATION}

\section{Corresponding Author}

*E-mail: enver.guler@atilim.edu.tr.

ORCID

Enver Güler: 0000-0001-9175-0920

Selmiye Alkan Gürsel: 0000-0002-7966-6352

Notes

The authors declare no competing financial interest.

\section{ACKNOWLEDGMENTS}

This research was funded by the Scientific and Technological Research Council of Turkey (TUBITAK; Project No. 213M023). We thank Burçin Yıldız for the assistance during NMR analyses.

\section{REFERENCES}

(1) Dodds, P. E.; Staffell, I.; Hawkes, A. D.; Li, F.; Grünewald, P.; McDowall, W.; Ekins, P. Hydrogen and Fuel Cell Technologies for Heating: A Review. Int. J. Hydrogen Energy 2015, 40 (5), 2065-2083.

(2) Zhou, X.; Qiao, J.; Yang, L.; Zhang, J. A Review of GrapheneBased Nanostructural Materials for Both Catalyst Supports and Metal- 
Free Catalysts in PEM Fuel Cell Oxygen Reduction Reactions. Adv. Energy Mater. 2014, 4 (8), 1301523.

(3) Elmer, T.; Worall, M.; Wu, S.; Riffat, S. B. Fuel Cell Technology for Domestic Built Environment Applications: State of-the-Art Review. Renewable Sustainable Energy Rev. 2015, 42, 913-931.

(4) Wang, Y.; Leung, D. Y. C.; Xuan, J.; Wang, H. A Review on Unitized Regenerative Fuel Cell Technologies, Part-A: Unitized Regenerative Proton Exchange Membrane Fuel Cells. Renewable Sustainable Energy Rev. 2016, 65, 961-977.

(5) Lucia, U. Overview on Fuel Cells. Renewable Sustainable Energy Rev. 2014, 30, 164-169.

(6) Carrette, L.; Friedrich, K. A.; Stimming, U. Fuel Cells Fundamentals and Applications. Fuel Cells 2001, 1 (1), 5-39.

(7) Sharaf, O. Z.; Orhan, M. F. An Overview of Fuel Cell Technology: Fundamentals and Applications. Renewable Sustainable Energy Rev. 2014, 32, 810-853.

(8) Wang, Y.; Chen, K. S.; Mishler, J.; Cho, S. C.; Adroher, X. C. A Review of Polymer Electrolyte Membrane Fuel Cells: Technology, Applications, and Needs on Fundamental Research. Appl. Energy 2011, 88 (4), 981-1007.

(9) Shao, Y.; Yin, G.; Gao, Y. Understanding and Approaches for the Durability Issues of Pt-Based Catalysts for PEM Fuel Cell. J. Power Sources 2007, 171 (2), 558-566.

(10) Sahoo, M.; Perez-page, M.; Kalangi, V.; Nair, R. R.; Holmes, S. Monolayer Graphene Based Membrane to Replace Nafion in PEM Fuel Cells. ECS Meet. Abstr. 2018, MA2018-01 (30), 1763.

(11) Wu, B.; Zhao, M.; Shi, W.; Liu, W.; Liu, J.; Xing, D.; Yao, Y.; Hou, Z.; Ming, P.; Gu, J.; Zou, Z. The Degradation Study of Nafion/ PTFE Composite Membrane in PEM Fuel Cell under Accelerated Stress Tests. Int. J. Hydrogen Energy 2014, 39 (26), 14381-14390.

(12) Chandan, A.; Hattenberger, M.; El-Kharouf, A.; Du, S.; Dhir, A.; Self, V.; Pollet, B. G.; Ingram, A.; Bujalski, W. High Temperature (HT) Polymer Electrolyte Membrane Fuel Cells (PEMFC)-A Review. J. Power Sources 2013, 231, 264-278.

(13) Kannan, A.; Kabza, A.; Scholta, J. Long Term Testing of StartStop Cycles on High Temperature PEM Fuel Cell Stack. J. Power Sources 2015, 277, 312-316.

(14) Gubler, L.; Gürsel, S. A.; Scherer, G. G. Radiation Grafted Membranes for Polymer Electrolyte Fuel Cells. Fuel Cells 2005, 5 (3), 317-335.

(15) Zhang, N.; Wang, B.; Zhao, C.; Zhang, Y.; Bu, F.; Cui, Y.; Li, X.; Na, H. Dual Cross-Linked Organic-Inorganic Hybrid Polymer Electrolyte Membranes Based on Quaternized Poly(Ether Ether Ketone) and (3-Aminopropyl)Triethoxysilane. J. Power Sources 2015, $275,815-822$.

(16) Nasef, M. M. Radiation-Grafted Membranes for Polymer Electrolyte Fuel Cells: Current Trends and Future Directions. Chem. Rev. 2014, 114 (24), 12278-12329.

(17) Rosli, R. E.; Sulong, A. B.; Daud, W. R. W.; Zulkifley, M. A.; Husaini, T.; Rosli, M. I.; Majlan, E. H.; Haque, M. A. A Review of High-Temperature Proton Exchange Membrane Fuel Cell (HTPEMFC) System. Int. J. Hydrogen Energy 2017, 42, 9293-9314.

(18) Bose, S.; Kuila, T.; Nguyen, T. X. H.; Kim, N. H.; Lau, K.; Lee, J. H. Polymer Membranes for High Temperature Proton Exchange Membrane Fuel Cell: Recent Advances and Challenges. Prog. Polym. Sci. 2011, 36 (6), 813-843.

(19) Qingfeng, L.; Hjuler, H. A.; Bjerrum, N. J. Phosphoric Acid Doped Polybenzimidazole Membranes: Physiochemical Characterization and Fuel Cell Applications. J. Appl. Electrochem. 2001, 31 (7), 773-779.

(20) Mack, F.; Aniol, K.; Ellwein, C.; Kerres, J.; Zeis, R. Novel Phosphoric Acid-Doped PBI-Blends as Membranes for High-Temperature PEM Fuel Cells. J. Mater. Chem. A 2015, 3 (20), 10864-10874.

(21) Asensio, J. A.; Sánchez, E. M.; Gómez-Romero, P. ProtonConducting Membranes Based on Benzimidazole Polymers for HighTemperature PEM Fuel Cells. A Chemical Quest. Chem. Soc. Rev. 2010, 39, 3210-3239.

(22) Sanl, L. I.; Tas, S.; Yürüm, Y.; Gürsel, S. A. Water Free Operated Phosphoric Acid Doped Radiation-Grafted Proton Con- ducting Membranes for High Temperature Polymer Electrolyte Membrane Fuel Cells. Fuel Cells 2014, 14 (6), 914-925.

(23) Wang, L.; Magliocca, E.; Cunningham, E. L.; Mustain, W. E.; Poynton, S. D.; Escudero-Cid, R.; Nasef, M. M.; Ponce-González, J.; Bance-Souahli, R.; Slade, R. C. T.; Whelligan, D. K.; Varcoe, J. R. An Optimised Synthesis of High Performance Radiation-Grafted AnionExchange Membranes. Green Chem. 2017, 19 (3), 831-843.

(24) Ponce-González, J.; Whelligan, D. K.; Wang, L.; Bance-Soualhi, R.; Wang, Y.; Peng, Y.; Peng, H.; Apperley, D. C.; Sarode, H. N.; Pandey, T. P.; Divekar, A. G.; Seifert, S.; Herring, A. M.; Zhuang, L.; Varcoe, J. R. High Performance Aliphatic-Heterocyclic BenzylQuaternary Ammonium Radiation-Grafted Anion-Exchange Membranes. Energy Environ. Sci. 2016, 9 (12), 3724-3735.

(25) Nasef, M. M.; Gürsel, S. A.; Karabelli, D.; Güven, O. RadiationGrafted Materials for Energy Conversion and Energy Storage Applications. Prog. Polym. Sci. 2016, 63, 1-41.

(26) Schmidt, C.; Schmidt-Naake, G. Proton Conducting Membranes Obtained by Doping Radiation-Grafted Basic Membrane Matrices with Phosphoric Acid. Macromol. Mater. Eng. 2007, 292 (10-11), 1164-1175.

(27) Nasef, M. M.; Hegazy, E.-S. A. Preparation and Applications of Ion Exchange Membranes by Radiation-Induced Graft Copolymerization of Polar Monomers onto Non-Polar Films. Prog. Polym. Sci. 2004, 29 (6), 499-561.

(28) Nasef, M. M.; Ali, A. A.; Saidi, H. Composite Proton Conducting Membrane by Radiation-Induced Grafting of 1 -Vinylimidazole onto Poly(Ethylene- Co -Tetrafluoroethylene) and Phosphoric Acid Doping. High Perform. Polym. 2013, 25 (2), 198204.

(29) Schmidt, C.; Schmidt-Naake, G. Grafting of 1-Vinylimidazole onto Pre-Irradiated ETFE Films. Macromol. Mater. Eng. 2007, 292 (10-11), 1067-1074.

(30) Lepit, A.; Aini, N. A.; Jaafar, N. K.; Hashim, N.; Ali, A. M. M.; Dahlan, K. Z. M.; Yahya, M. Z. A. Influences of Co-Polymerization 1Vinylimidazole onto $\gamma$-Irradiated Poly(Vinylidene Flouride) Membranes. Int. J. Electrochem. Sci. 2012, 7, 8560-8577.

(31) Tazuke, S.; Okamura, S. Salt Effects on Vinyl Polymerization A Boundary Study of Organic and Inorganic Chemistry. Pure Appl. Chem. 1970, 24 (1), 49-66.

(32) Garnett, J. L.; Jankiewicz, S. V.; Sangster, D. F. Mechanistic Aspects of the Acid and Salt Effect in Radiation Grafting. Int. J. Radiat. Appl. Instrumentation. Part C. Radiat. Phys. Chem. 1990, 36 (4), 571579.

(33) Wang, L.; Brink, J. J.; Liu, Y.; Herring, A. M.; Ponce-González, J.; Whelligan, D. K.; Varcoe, J. R. Non-Fluorinated Pre-IrradiationGrafted (Peroxidated) LDPE-Based Anion-Exchange Membranes with High Performance and Stability. Energy Environ. Sci. 2017, 10, 2154-2167.

(34) Schmidt-Naake, G.; Böhme, M.; Cabrera, A. Synthesis of Proton Exchange Membranes with Pendent Phosphonic Acid Groups by Irradiation Grafting of VBC. Chem. Eng. Technol. 2005, 28 (6), $720-724$.

(35) Işıkel Şanll, L.; Alkan Gürsel, S. Synthesis and Characterization of Novel Graft Copolymers by Radiation-Induced Grafting. J. Appl. Polym. Sci. 2011, 120 (4), 2313-2323.

(36) Güler, E.; Sadeghi, S.; Alkan Gürsel, S. Characterization and Fuel Cell Performance of Divinylbenzene Crosslinked Phosphoric Acid Doped Membranes Based on 4-Vinylpyridine Grafting onto Poly(Ethylene-Co-Tetrafluoroethylene) Films. Int. J. Hydrogen Energy 2018, 43 (16), 8088-8099.

(37) Sadeghi, S.; Işıkel Şanlı, L.; Güler, E.; Alkan Gürsel, S. Enhancing Proton Conductivity via Sub-Micron Structures in Proton Conducting Membranes Originating from Sulfonated PVDF Powder by Radiation-Induced Grafting. Solid State Ionics 2018, 314, 66-73.

(38) $0.5 \mathrm{mg} / \mathrm{cm}^{2} 60 \%$ Platinum on Vulcan - Carbon Paper Electrode; Fuel Cell Store: https://www.fuelcellstore.com/05-ptc-paperelectrode?search=fuel (accessed Dec. 16, 2019).

(39) Nasef, M. M.; Shamsaei, E.; Saidi, H.; Ahmad, A.; Dahlan, K. Z. M. Preparation and Characterization of Phosphoric Acid Composite 
Membrane by Radiation Induced Grafting of 4-Vinylpyridine onto Poly(Ethylene-Co-Tetrafluoroethylene) Followed by Phosphoric Acid Doping. J. Appl. Polym. Sci. 2013, 128 (1), 549-557.

(40) Bozzi, A.; Chapiro, A. Synthesis of Perm-Selective Membranes by Grafting Acrylic Acid into Air-Irradiated Teflon-FEP Films. Int. J. Radiat. Appl. Instrumentation. Part C. Radiat. Phys. Chem. 1988, 32 (2), 193-196.

(41) Gürsel, S. A.; youcef, H. B.; Wokaun, A.; Scherer, G. G. Influence of Reaction Parameters on Grafting of Styrene into Poly(Ethylene-Alt-Tetrafluoroethylene) Films. Nucl. Instrum. Methods Phys. Res., Sect. B 2007, 265 (1), 198-203.

(42) Rath, S. K.; Palai, A.; Rao, S.; Chandrasekhar, L.; Patri, M. Effect of Solvents in Radiation-Induced Grafting of 4-Vinyl Pyridine onto Fluorinated Ethylene Propylene Copolymer. J. Appl. Polym. Sci. 2008, 108 (6), 4065-4071.

(43) Hansen, C. M. Hansen Solubility Parameters: A User's Handbook; CRC Press, 2007; DOI: 10.1201/9781420006834.

(44) Li, Q. Water Uptake and Acid Doping of Polybenzimidazoles as Electrolyte Membranes for Fuel Cells. Solid State Ionics 2004, 168 (1-2), 177-185.

(45) Kreuer, K.-D.; Paddison, S. J.; Spohr, E.; Schuster, M. Transport in Proton Conductors for Fuel-Cell Applications: Simulations, Elementary Reactions, and Phenomenology. Chem. Rev. 2004, 104 (10), 4637-4678.

(46) Nasef, M. M.; Aly, A. A.; Saidi, H.; Ahmad, A. Optimization of Reaction Parameters of Radiation Induced Grafting of 1-Vinylimidazole onto Poly(Ethylene-Co-Tetraflouroethene) Using Response Surface Method. Radiat. Phys. Chem. 2011, 80 (11), 12221227.

(47) Lázaro Martínez, J. M.; Leal Denis, M. F.; Campo Dall'Orto, V.; Buldain, G. Y. Synthesis, FTIR, Solid-State NMR and SEM Studies of Novel Polyampholytes or Polyelectrolytes Obtained from EGDE, MAA and Imidazoles. Eur. Polym. J. 2008, 44 (2), 392-407.

(48) Domján, A.; Fodor, C.; Kovács, S.; Marek, T.; Iván, B.; Süvegh, K. Anomalous Swelling Behavior of Poly(N-Vinylimidazole)-1Poly(Tetrahydrofuran) Amphiphilic Conetwork in Water Studied by Solid-State NMR and Positron Annihilation Lifetime Spectroscopy. Macromolecules 2012, 45 (18), 7557-7565. 